University of South Florida

DIGITAL COMMONS

Digital Commons @ University of

@ UNIVERSITY OF SOUTH FLORIDA

South Florida

Government and International Affairs Faculty

Publications

Government and International Affairs

$5-2014$

\title{
Communication, Class and Concentric Media Practices: Developing a Contemporary Rubric
}

Todd Wolfson

Rutgers University, twolfson@cri.rutgers.edu

Peter N. Funke

University of South Florida, pnfunke@usf.edu

Follow this and additional works at: https://digitalcommons.usf.edu/gia_facpub

Part of the International Relations Commons

\section{Scholar Commons Citation}

Wolfson, Todd and Funke, Peter N., "Communication, Class and Concentric Media Practices: Developing a Contemporary Rubric" (2014). Government and International Affairs Faculty Publications. 121.

https://digitalcommons.usf.edu/gia_facpub/121

This Article is brought to you for free and open access by the Government and International Affairs at Digital Commons @ University of South Florida. It has been accepted for inclusion in Government and International Affairs Faculty Publications by an authorized administrator of Digital Commons @ University of South Florida. For more information, please contact digitalcommons@usf.edu. 


\section{Communication, Class and Concentric Media Practices: Developing a Contemporary}

\section{Rubric $^{\mathrm{i}}$}

In:

“Communication, Class and Concentric Media Practices: Developing a Contemporary Rubric”, New Media \& Society, Volume16, Issue 3, May 2014, pp. 363-380

\section{Peter Nikolaus Funke}

Department of Government and International Affairs, University of South Florida pnfunke@usf.edu

http://gia.usf.edu/faculty/pfunke/

1-(215) 385-6151

Department of Government and International Affairs, University of South Florida

4202 East Fowler Avenue, CIS 1040

Tampa, FL 33620-9951

USA

\section{Todd Wolfson}

Department of Journalism and Media Studies, Rutgers University

twolfson@rci.rutgers.edu

School of Communication and Information, Rutgers University

4 Huntington St

New Brunswick, NJ 08901

USA 


\section{'Biography'}

Todd Wolfson is Assistant Professor in the Department of Journalism and Media Studies at Rutgers University. Dr. Wolfson's research and work in the community is focused on the intersection of social movements, global capitalism and media.

Peter Nikolaus Funke is Assistant Professor in the Department of Government and International Affairs at the University of South Florida in Tampa. Dr. Funke's research focuses on social movements, new media and class formation under globalizing capitalism. Currently, he is working on a book length study of the World Social Forum. 
Communication can alone create a great

community. Our Babel is not one of tongues

but of signs and symbols without which

shared experience is impossible

John Dewey, The Eclipse of the Public

\section{I}

\section{Introduction}

Exploring the ongoing dynamics of a network of organizations across Philadelphia, this article looks at the role of new media and communications in the construction of contemporary class formation. The widespread assumption is that we are living in a moment of societal flux (economic, technological, political) in which old forms of collective identity have disappeared. Specifically, class identity is considered a bygone logic of the industrial era, which has given way to more fluid forms of collective identity revolving around more discernible signifiers such as gender or race. While it is critical to study these forms of collective identity, socio-economic class as an axis through which life is experienced, has hardly disappeared. This is particularly the case across the last forty years, in which we have seen a dwindling middle class and increasing impoverishment across the U.S. and beyond. Consequently, the formation of collective selves around socio-economic class is a pivotal and currently understudied axis for establishing and maintaining group identity (Funke, 2012).

Based on an understanding of class as a process of self-making in relation to a particular, historical form of capitalism - in this case neoliberal capitalism - we argue that media and communication must be conceptualized as an emerging structural dimension for class formation. Due to the increasingly atomized, isolated nature of social life as well as the apparent splintering 
of the working class under neoliberal capitalism, media or rather the use of its potentials serves a pivotal infrastructural or, as we shall label it, "suturial” function for generating the necessary commonality between the fractured sectors of the contemporary working class.

While communication has always been of central importance for the production of class identity (Marx, 1978), we maintain that neoliberal capitalism and the corresponding social relations that have emerged structurally elevate the role of media for class formation. More specifically, the global economic processes of neoliberal capitalism have transformed cities like Philadelphia—a transformation that has led to a mixture of service sector, casualized working conditions (Brenner and Theodore, 2002; Harvey, 2005), fragmented and segregated neighborhoods (Massey and Denton, 1998; Smith, 1996), the privatization of urban public space (Davis, 1992) and social services (Marcuse \& Van Klempen, 2002; Smith, 1996) and a growing number of people living in poverty that are isolated and disengaged from the political process (Goode and Maskovsky, 2001). The ensuing atomized and increasingly isolated nature of social life (Giddens 1991; Lash and Urry, 1987) frames the contemporary city. Consequently, we argue that media and communication serve a pivotal infrastructural function for generating unity between these fractured sectors of the working class. As such, we suggest that media operates as a structural dimensions for class formation, having the ability to shape and organize social relations across the fragmented working class.

In this article, we look at the practices of the Media Mobilizing Project (MMP) as a vehicle for understanding the role of media and communication in bridging and thus suturing the distance between the multiple subject positions of the contemporary working class. MMP is both a community-based media and communications infrastructure and a network of organizations across the Philadelphia region (Berger, et. al., 2011) that aim to "build a movement 
to end poverty led by the poor and working class, united across color lines.” The central tactic of the Media Mobilizing Project is to utilize media (radio, video, web) as the "nervous system" that conjoins and sutures people across the fragmented political topography of the region. At the heart of MMP's work is the aim of building the power of poor and working people, with the larger goal of creating transformative structural social change.

This article is based on ethnographic fieldwork, which happened from 2008 to 2011. The research entailed: document collection, participant observation and semi-structured interviews. Participant observation took place across a diverse array of MMP activities and domains including workshops, protests as well as the day-to day environment at MMP's office. Alongside participant observation the research included approximately twenty interviews across the broad membership of MMP. Interview subjects consisted of MMP cofounders, volunteers, and leaders from MMP member groups as well as workshop participants. Further, the research had an engaged aspect (Hale, 2008; Sanday, 1976), as Todd Wolfson is both a professor of media studies and a founding member of MMP. The author's engaged role was critical in getting a deeper more detailed understanding of MMP processes and practices, while this is balanced by the Peter Funke’s more distanced relationship to MMP.

Based on our research, we have developed an approach to class formation and the role of communication that we call concentric practices. These concentric practices provide us with a conceptual framework of how contemporary class formation is occurring through the use of media and communications in a neoliberalizing city such as Philadelphia. We see this complex of interrelated dynamics as illustrative of the process of thickening and converging that occurs across the atomized working class through the realization of media and communication potentials. This concept, while embedded in MMP practice, is not strategically outlined by the 
organization, but it is something we have discerned through research.

MMP's concentric practices can heuristically be analyzed along three overlapping processes, which establish a "common" among the different fragments of the working class: communicative spaces, narrative practices and shared struggles. Simply and somewhat schematically put, communicative spaces lay the groundwork for bringing people together in the "same room," for starting to share experiences, for providing the necessary knowledge of the technical tools of our time as well as for generating the necessary analytic skills. Narrative practices then "channel" the beginnings of communality as well as the skills built through communicative spaces, framing and directing them to then lead into shared struggles based on the realization of a shared class identity. Together these concentric practices form the basis of our argument, that media and communication (from face-to-face and old mediums such as radio to internet-powered tools) emerge as a necessary infrastructural dimension for the process of realizing commonalities and generating class identity across the now physically and often cognitively isolated sectors of the neoliberal working class. Media not only allows for communication across the now increasingly dispersed working class sectors but communication and media, we hold, is becoming a constitutive and suturial dimension for generating collective identity. Class formation under neoliberal capitalism, we argue, thus increasingly relies on diverse communicative practices and various media tools, which are used by organizers to generate interconnections, convergences, and ultimately class consciousness.

In the following, we track the flow of stories and communicative practices, as they weave their way from cab drivers and urban high school students to health care and hotel workers. Our aim is to shed light on the ways MMP organizers use media practices to knit this diverse class 
into a shared tapestry, and as such we seek to begin conceptualizing the relationship between concepts of social identity and communications in neoliberal capitalism.

\section{II}

\section{Class Formation as a Structured Process}

In The Poverty of Philosophy, Karl Marx (1978) argued that class emerges within the context of objective socio-political structures but that it is within struggle that a class in itself becomes a class for itself:

Economic conditions had first transformed the mass of the people of the country into workers. The combination of capital has created for this mass a common situation, common interests. This mass is thus already a class as against capital, but not yet for itself. In the struggle... this mass becomes united, and constitutes itself as a class for itself. The interests it defends becomes class interests. (Marx, 1978: 218)

Marx argued that class is objectively determined under capitalism via the exploitative relationship between the proprietors of the means of production and those who own only their labor-power while at the same time stressing that class becomes subjectively defined through consciousness.

E.P. Thompson expands on this understanding. For Thompson, class emerges on the basis of the objective structures of capitalism. In order for this structurally generated "class in itself” to assert itself meaningfully, however, it needs structured processes of collective agency, which forge class identity and class-consciousness and thus generate the "class for itself.” As Thompson writes in the preface of The Making of the English Working Class,”

[b]y class I understand a historical phenomenon, unifying a number of disparate and seemingly unconnected events, both in the raw material of experience and in consciousness. I emphasize that it is an historical phenomenon. I do not see class as a 'structure', nor even as a 'category', but as something, which in fact happens (and can be shown to have happened) in human relationships. (Thompson, 1966: 9) 
In "The Poverty of Theory", Thompson is even more direct, stressing that

[c]lasses arise because men and women, in determinative productive relations, identify their antagonistic interests, and come to struggle, to think and to value in class ways: thus the process of class formation is a process of self-making, although under conditions which are 'given'. (Thompson, 1978: 106-107)

While Thompson's understanding of class has been critiqued (Anderson, 1980), Ellen Meiksins Wood summarizes the debate, capturing the strength of his perspective. She writes, “[w]here Thompson's critics see structures as against process, or structures that undergo process, Thompson sees structured processes.” (1995: 79). Informed by Thompson’s historical extension of Marx, this article recognizes class as something that happens through structured processes. By this we mean that while people's structurally determined objective conditions (today neoliberal capitalism) are key to creating a set of shared social circumstances (precarious working situations, debt, underperforming public schools, etc.), it is through a set of collectivizing processes that classes of people recognize these common conditions. Put differently, “class in itself” exists on the objective basis of the capitalist structures of production, whereas the same working class only becomes a "class for itself” through developments that include processes of self-making within these given structures (Lukacs, 1968 [1923]).

\section{Capitalism and Class in History}

Our notion of class as something that develops through structured processes is based on an understanding of capitalism as a historical phenomenon (Boltanski and Chiapello, 2005; Mandel, 1978), and thus of capitalist societies as changing over time and space. Correspondingly, we see class in the twenty-first century as a transforming object characterized by the expanding sphere and changing nature of capitalist exploitation under a neoliberal ethos. 
In the industrial era, the generalized belief was that capital accumulation came from fixed investments and economies of scale. The logic of stable, fixed capital accumulation had social and political consequences as the working class tended to toil together in large factories, mines and docks, leading to a physical and cognitive/cultural proximity, which allowed workers to share experiences and build solidarity.

Across the last forty years however, the intensive and extensive growth of globalizing capitalism (Harvey, 1990, 2005; Robinson, 2004), has expanded and deepened the reach of capitalism's logic, forging a global division of labor while penetrating into what were once public sectors of society such as education and health care. These shifts towards neoliberal capitalism or what autonomists Mario Tronti and later Antonio Negri call the "social factory" (Negri, 1989) or the "global social factory" (Funke, 2010) have had material outcomes, changing the nature of the urban United States working class, from industrial workers, to largely service sector workers.

The similar life and working conditions of the industrial working class during Fordism stands in contrast to the arguably more diverse modalities of neoliberal class exploitation of, for instance, taxi drivers or janitors. ${ }^{\text {ii }}$ The neoliberal working class is thus both expanding as new parts of the population fall under the capitalist logic, as well as fragmenting, as the urban servicesector working class is more isolated than the industrial proletariat. Given their atomized and isolated societal positioning, the neoliberal working class faces a more challenging prospect of generating relations and thus a different and arguably more complex process of constructing class identity.

Class and Communication 
Building on both our understanding of the process of class formation and the historical nature of capitalism and capitalist relations, in this section we consider the role of communications in class formation. Returning to Marx, in The Eighteenth Brumaire of Louis Bonaparte, he set out to use the French example to understand the difference in class unity between the peasantry and proletariat. Marx noted:

The small peasants form a vast mass, the members of which live in similar conditions, but without entering into manifold relations with one another. Their mode of production isolates them from one another instead of bringing them into mutual intercourse. The isolation is increased by France's bad means of communication and by the poverty of the peasants. (1978: 124)

Following this Marx sets forth an often-overlooked axiom of class theory:

Insofar as there is merely a local interconnection among these small-holding peasants, and the identity of their interests begets no community, no national bond and no political organization among them, they do not form a class. They are consequently incapable of enforcing their class interest in their own name, whether through a parliament or through a convention. They cannot represent themselves, they must be represented. (1978: 124)

The significance of this statement, as Hardt and Negri recognize (2004), is that in Marx's analysis it is the lack of an internal communications infrastructure and circuits of social cooperation of the French peasantry, which hinder their ability to be a class and represent their interests to the larger French community. In essence, the inability to communicate leads to an inability to represent. This prompted Hardt and Negri to argue that lines of internal communication are necessary for establishing political subjectivity and identity, arguing:

Communication in this sense, is the key to the political significance of the traditional division between city and country and the political prejudice for urban political actors...not so much idiocy but incommunicability defined rural life. The circuits of communication that gave the urban working class a great political advantage over the rural peasantry were also due to conditions of work. The industrial labor force, working in teams around a common machine, is defined by cooperation and communication, which allows it to become active and emerge as a political subject. (2004: 123) 
Marx's statement and Hardt and Negri's interpretation, offer a vehicle for examining the role of communication in class formation. However, both Marx and Hardt and Negri do not offer concrete analysis for what this means in the practices of everyday life. Along these lines, we argue that old and new information and communication technologies are increasingly becoming infrastructural dimensions for class formation under neoliberal capitalism as the life and work experiences of the contemporary working class sectors are arguably more diverse. Thus, in order to bridge the manifest yet epiphenomenal differences in life and work experiences, we argue, necessitates communicative processes that run deeper and wider than might have been the case during Fordism: "deeper" in the sense of having to penetrate the surface expressions of the dissimilar living and working conditions of the contemporary working class sectors to bring forth the structural similarities between them; "wider" in the sense of having to expand, to interlink the dispersed sectors of the neoliberal working class, which is no longer converging at conveyer belts but inhabit life worlds that appear disconnected, working in cabs and hospitals or cleaning emptied office buildings early in the morning. We argue that media, including new media, emerges as a necessary dimension in addition to face-to-face interactions for the process of realizing commonalities and generating class identity across the now physically and cognitively isolated sectors and members of the working class.

The remainder of this article illustrates the suturial function of media by focusing on the Media Mobilizing Project. We argue that this sense of a shared identity develops through a series of media sutured and interlinked concentric practices, from building trust and a sense of the common through face-to-face encounters, to deconstructing the mass media's bias and creating alternative messages, to coming out together in shared struggle. 


\section{III}

\section{Concentric Practices: The Media Mobilizing Project and Media As Suture}

MMP was first established in 2005, as a project within the Philadelphia Independent Media Center, during a local campaign against Wal-Mart spearheaded by the local Philadelphia Jobs With Justice (JWJ). During the campaign, the eventual founders of MMP worked with JWJ to bring a participatory media aspect to the campaign. MMP held community journalism trainings with local union members and then brought people to a Wal-Mart to interview employees on issues of working conditions. These interviews became the basis of a series of short videos on Wal-Mart. The Wal-Mart campaign was successful, and building on the experience, six founders came together to establish MMP in a formal sense.

The founders of MMP have their roots in antipoverty and poor people’s organizing (Baptist and Rehmann 2011) as well as in the participatory media making that surfaced most prominently through the indymedia movement (Kidd, 2003; Wolfson, 2011) since the World Trade Organization protests in Seattle in 1999. MMP seeks to merge these two dimensions in an effort to join class-based social movement building work with a focus on the role of media and communications in binding across points of struggles. To this end, MMP focuses on building the political power and emancipatory potential of poor and working class communities across the greater Philadelphia community. The specific aim of MMP has been to both create professional media as well as train people to tell their own story in an attempt to build a narrative about poor and working people that is both polished and comes from the voices of those in struggle.

With a focus on using media to organize and connect the often atomized and diverse poor and working-class groups and organizations, MMP sees itself as a corrective to some of the perceived problems of the indymedia movement (Wolfson, 2012). As one of the founders, Dave 
Walker expressed, 'we wanted to distill the lessons of indymedia particularly in using media to connect struggles and divorce that from the inability of indymedia to build with poor and working class communities.' Along these lines, MMP uses the array of communication mediums as a central device for forging class-identity as we now turn to discuss.

MMP illustrates communication’s structural dimension for class formation and provides a particular example of how media is used to suture class identity. MMP operates as a network of organizations for poor and working people that utilize media and communications as a "core strategy for building a movement to end poverty led by the poor and working class and united across color lines” (MMP, 2009). Specifically, through a host of old and new media platforms (radio, video, web) MMP works with different segments of Philadelphia’s working class such as immigrants, urban youth, and low-wage workers. Through MMP we illustrate how media and communication has become a "suture,” interweaving the diverse groups and galvanizing their class-based identity.

While we recognize the rather technical manner through which the term suture is employed in cinematic studies, to signify a series of shots and the correspondent interpellated audience/subject, we use the term to emphasize the process of constructing class identity through media. We understand the concept of "suturing” as an intervention both at the collective as well as the individual level. In the case of the former, media "stitches" the atomized sectors of the neoliberal working class into diverse formations and in case of the latter, media sutures by transforming “individuals into subjects” in Althusser’s terms (1971: 174). Put simply, suturing works to create a common across the different subdivisions of the neoliberal working classfrom industrial workers to janitors and immigrant domestic workers - while also working at the more intimate level of galvanizing a collective identity amongst individuals. Building on 
Althusser, Stuart Hall focuses on suturing as a two-sided process or articulation that is better understood as a positioning than an essence (1994: 226). Informed by Althusser and Hall's understanding, we conceptualize suturing as a process of aligning, of solidifying the formation of class identity. We see suturing as working at the level of the individual, calling them into a class formation as well as functioning across the isolated sectors of the neoliberal working class, forging unity across different life and work experiences.

In the following, we focus on three practices. First we look at communicative spaces, which are the face-to-face trainings, media screenings, community dinners and other collective moments where people are brought together in an effort to "build community." Second, we look at narrative practices, where MMP media makers aim to craft messages that place different points of resistance in a shared frame to build a common understanding of struggle, thus linking first generation South Asian cab drivers, to African-American urban youth, and working class white nurses. Third we look at shared struggles, which are the moments when different MMP organizations support one another in particular fights—-from the right of cab drivers to unionize to the right of urban youth to a quality education.

These three suturing dimensions we conceptualize as concentric practices (see Figure 1 on page 15) with one including the other. As a heuristic device, the communicative spaces would then describe the shared center, a necessary part for the narrative practices. Both the communicative spaces and narrative practices would then be necessary (but not sufficient) to constitute and generate the practice of shared struggles. While the particularities of how media is employed to forge class identity (here concentric practices) is context specific, MMP provides us with a conceptual framework of how contemporary class formation is occurring through the use of media and communications in a neoliberalizing city such as Philadelphia. 


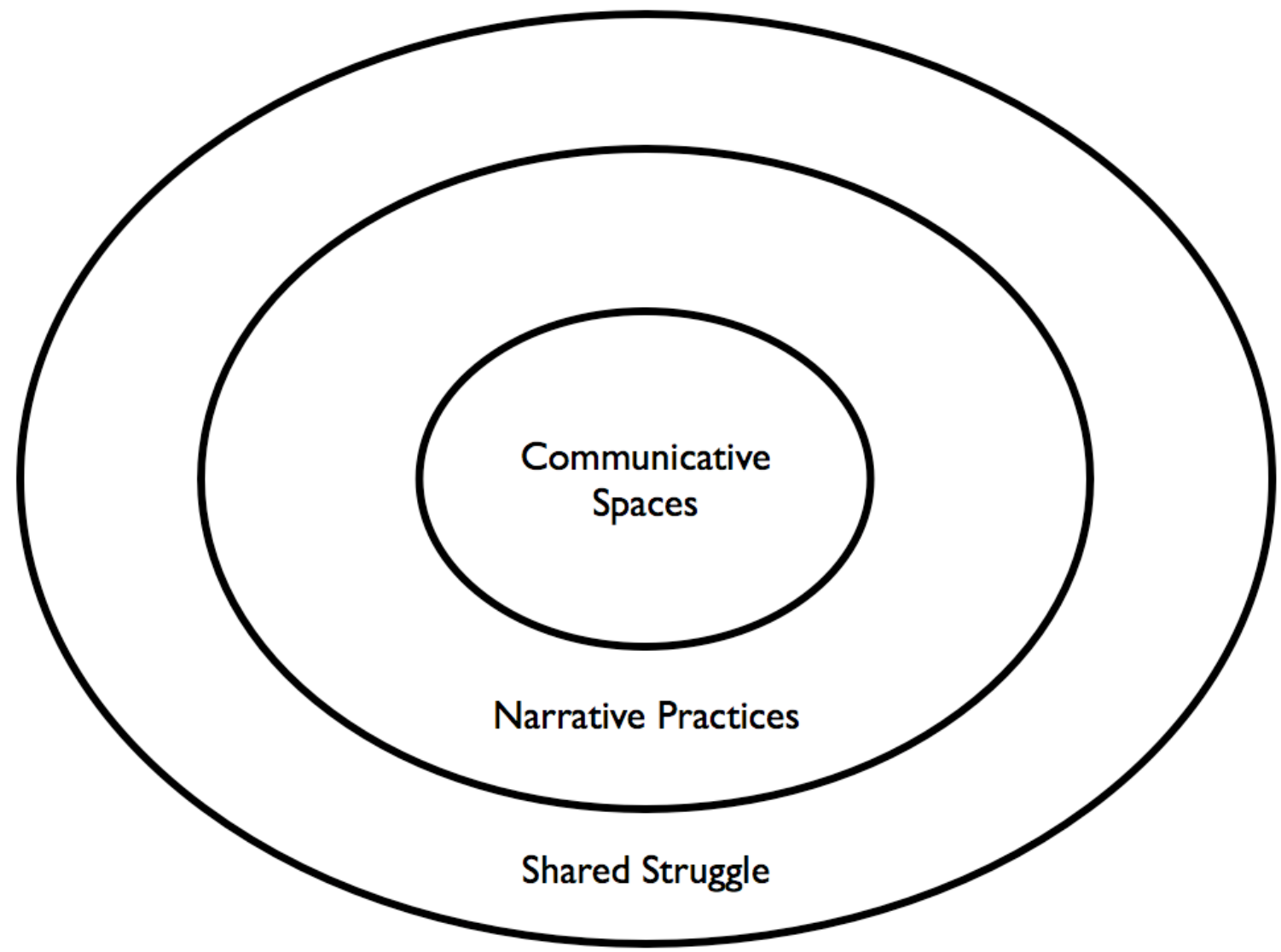

Figure 1-This Diagram of Concentric Practices, illustrates the process of class formation through media. iii

Communicative Spaces:

In the era of globalizing capitalism, “space between” is a key characteristic, which defines our autonomy and individuated experiences. This expanse of space, both physical and experiential, must be challenged if movements are to build shared identity through common experiences. MMP undertakes this work, through what we call communicative spaces, such as weekly political education studies, media and communications training programs, community building dinners, and media screenings. Utilizing these physical spaces to build trust and shared 
identity is not unique to MMP as it is also a model upon which the World Social forum process (Funke, 2012) was built.

In the case of the Media Mobilizing Project (MMP), these communicative spaces are utilized as key moments where people who are differently situated come to see the "common" across their unique situations. The most prominent example is the Community Building Dinner (CBD), which MMP has held annually since 2006, for movement leaders across the region. In 2009, the dinner brought together approximately 150 people who represented a host of struggles, from urban youth and people fighting against displacement and gentrification to nurses, janitors, taxi drivers, restaurant workers, security guards, and sanitation workers among others

As Dana Harvey, one of the organizers of the dinner explains, “we are very intentional in how we plan the program and coordinate seating.” Dana went on to detail that "the table seating is done to make sure people are sat with people they know, but also have the opportunity to meet and discuss their work and struggle with organizers from other sectors in the city.” Dana then discussed a game they organized during the CBD where people answer practical questions about the work and organizing of other groups and individuals at the dinner, which gives attendants a chance to learn about different struggles. The point as she explained, was to "familiarize people with one another but also show how are experiences and fights are connected.”

Each year the CBD also consists of a talk from a leader in the community and the screening of an MMP montage, a 10-minute video that details some of the important organizing work that has taken place in the previous year. In 2009, Cathy Scott, president of a Philadelphia municipal union, A.F.S.C.M.E District Council 47, spoke. Scott explained that it was likely that municipal workers would go on strike in the coming year, and it was important for Philadelphians to join and support public workers. Following her talk, the annually produced 
montage of MMP's work and struggles of the past year was screened. One of the creators of the montage, Tina George explained that the aim of the video was to create a theme that places different points of struggle side-by-side, capturing the character of struggle in a particular year.

The 2009 montage, which was purposefully translated into Spanish to reach immigrant workers, opened by focusing on the sweeping economic crisis, and its impact on the people of the region. Then, as if taking a cue from Thompson's precept—-class happens when some men... articulate the identity of their interests as between themselves, and as against other men whose interests are different from (and usually opposed) theirs," - the video focuses on a shared enemy. Against the backdrop of familiar points of resistance across the city, from gentrifying neighborhoods to sites of recent workers' struggles, the narrator of the video intones:

We are up against forces that know clearly amongst themselves, that they shared a common agenda and a common vision... we are up against forces that are sophisticated and act upon our lives in a coordinated fashion... this is how they are able to maintain the control, the influence and the hold on the status quo under which half of our city suffers. (MMP, 2009)

The aim of the montage was to show that there is a shared "adversary" while detailing the multiple points of struggle and common experiences that link people together-from transit workers, immigrants and youth to cab drivers and anti-casino organizers. After the montage aired, one of the hosts got on stage and called out the names of every organization represented at the dinner and then exclaimed, "We are as organized as they are!"

What becomes clear in an analysis of the CBD is that the aim of the organizers is to create physical spaces where people come together and learn about one another's struggles so they can build trust and find their “common.” This tactic is consistent across all of MMP's work. As MMP organizer, Mark Williams explains, "while we see new technologies as key, we first 
want people to see and know one another and build a sense of understanding and trust, which of course develops over time.”

Another example of communicative spaces is demonstrated through MMP’s video training program: Our City Our Voices (OCOV). OCOV was a joint project between MMP and Juntos, a local community organization dedicated to the rights of Spanish-speaking immigrants. The idea for OCOV developed during the national protests for immigrant rights in 2006. Members of MMP and Juntos recognized a lack of immigrant voices in the debate around immigration reform and they saw immigrants as isolated from other sectors of the working class. In response, the aim of OCOV was two-fold. First, train immigrants and other low-wage workers in basic journalism and video production. Second, use the City’s new municipal wireless broadband network as a central backbone for sharing these stories, in an effort to challenge the dominant discourse. The two groups also wanted to bring Spanish-speaking immigrants into contact with other immigrant communities as well as low-wage workers.

Supported by a grant from the Knight Foundation, OCOV’s worker-based video production classes, were eight weeks long. The workshop was structured in two parts. During the first section, students were trained in video and web skills as well as basic journalism and media literacy. In the second section the students went out and made videos about issues they were facing as immigrants and low-wage workers. The workshop and its products exemplify the strategic use of media for class formation. The students were selected from groups and communities that MMP targeted as important elements of a bigger movement.

In the case of OCOV this strategy was successful as the videos have been instrumental in forging tighter connections among MMP networked groups, revealing the similarities between their struggles and prompting the further generating of cooperation and convergence. As one 
student, Nawala Uusiku, a West African immigrant and organizer with UNITE HERE, pointed out, through this class "we kind of developed this sense of community.... We are from different organizations but we became this community.”

In the case of OCOV, the development of a shared community did not come without struggle. During OCOV, conflict emerged between MMP and Juntos on the best structure for the class. The disagreement centered on participants in the class. One of the Juntos trainers believed that the course should exclusively focus on immigrants and not American-born participants, because there are few opportunities for immigrants to learn media skills. MMP organizers on the other hand, felt it was important to create a mixed environment, bringing in other low-income students from service-sector unions, SEIU and UNITE-HERE, in order to break isolation between immigrants and other workers. Ultimately the class was integrated, and the students, regardless of citizenship status, built a strong and meaningful learning community. That said the divergence over who should be allowed in the class marks the boundary MMP aims to bridge, and therefore conflict is something that is constantly managed.

The MMP point people for OCOV were Perchik and Dara. Dara, a native from the greater Philadelphia area, has a background in media studies. Originally from San Francisco, Perchik moved to Philadelphia about five years ago. She has a degree in film from the University of California at Santa Cruz and taught video classes for several years in Austin, Texas.

During the day, students in OCOV were taught media skills while discussing the problems with mainstream media. As part of this process the instructors addressed the need for net neutrality and municipal wireless systems to close the digital divide, and learners made videos detailing gentrification and problems in Brewerytown, the North Philadelphia neighborhood where the class was held. In this sense, a class on video production became a 
space for connecting media reform issues to peoples' lives as well as to broader urban challenges

of impoverished neighborhoods and the politics of gentrification.

Much like the Community Building Dinner, the off-line relationship building in OCOV

was crucial for cross-group networking. As Perchik explained:

[E]ven these classes and workshops were working within that framework of allowing people to have the space and access to tell their own stories but also to be able to then later plug in to MMP and cover events, their own events or other people in other networks, to build alliances with each other's struggles, which was amazing to actually see happening cause I have been working with MMP for a long time and have been hearing about connections of various networks and building this giant movement and its really hard to sometimes see that and that big vision. But it was amazing because even when we were working with PSU [Philadelphia Student Union] specifically we were going covering the taxi cab workers' events and UNITE HERE and other union events, watching how everyone was actually showing up to each others work and really participating. ... I felt like it even heightened the importance of these skills and see that people can provide that for one another in their various struggles and also in their own.

OCOV's success led organizers to design a strategy for more continuous cross-group fertilization and self-empowerment. As such, in the fall of 2008, OCOV initiated "master classes" for those that went through the initial training cycle. As Dara explains:

The idea is to sort of form a group of people that then can be active, out filming events and documenting meetings or issues that are coming up in a timely way and sort of turning them around on the blog in a fashion that is a fast production model. ... [The goal is to] train people that then can become autonomous kind of working units. So the master class would be like the meeting point for all of those people in a regular way but in between that there would be sense that these are the activities that are going on this week or this month and who is available to cover this.

MMP’s video training program “Our City Our Voices” and MMP’s annual community dinner illustrate the use of what we call communicative spaces as a core practice of seeking to form class identity on the basis of the various groups' analogous relation to neoliberal capitalism. In these communicative spaces the different MMP affiliated working class segments congregate 
and start to forge a common that transverses their unique life and working situations. The critical aspect that emerged through these shared spaces was the process of creating trust amongst fragmented communities as well as a shared understanding of the socio-economic conditions poor and working people face, a task that overlaps with narrative practices to which we now turn.

\section{Narrative Practices:}

The example of Our City Our Voices reaches into the narrative practices part of the concentric practices model, as it illustrates the use of media and communication to forge class identity. The community dinner as well as OCOV enable communicative spaces by providing venues for face-to-face trainings, media screenings, and other collective moments people are brought together in an effort to "build community.” OCOV also exemplifies MMP’s attempts to craft messages that place different segments of the neoliberal working class in a shared frame to build a common understanding of struggles. As such, OCOV as a narrative practice channels the emerging notion of communality through framing and directing.

MMP’s Labor Justice Radio (LJR) provides another insightful illustration of how MMP engages in narrative practices to forge a class identity across the fragmented urban working class. LJR airs on West Philadelphia's community radio station WPEB 88.1FM. It has aired since September 5, 2008, as a monthly hour-long radio program that "advocates justice for all working people” (http://www.podomatic.com/profile/laborjusticeradio). It is the first radio show in the city that is "collaboratively produced by workers and labor leaders from across the taxi, service and commercial industries” (http://www.phillyimc.org/en/node/73672). The show focuses on local issues around workers' justice. There are typically four stories of five-minute 
length, per show, as well as discussion and music segments. The first show, for instance, included segments on UNITE HERE's boycott of Embassy Suites, recent immigration raids that targeted members of SEIU 32BJ, and two pieces on taxi workers: one about the creation of the Unified Taxis Workers Alliance of PA, and the other about efforts to win workers' compensation for injured taxi drivers. Labor Justice Radio provides a space for poor and working class people from MMP's different groups to work together, to build deeper relationships, and thus to foster an ever tighter network.

Building the critical analytic skills of people in MMP and its affiliated groups is essential to this process. As Sarah McKay who leads the radio trainings and is the coordinator of all MMP radio programs put it in an interview with us, the trainings are designed to help people produce stories that either support a group’s organizing or assists the listener "make some connection that they didn’t have before.” However, the connections are not only generated through the final product and thus online - or in this case on air. The process of putting the shows together as McKay points out, fosters “a shared class identity” among the groups involved. Much more than the radio program itself, which currently can only be heard in West Philadelphia, McKay sees media and communication as tools for "carving out more and more space” for poor and working people.

Reflecting on the class afterward, McKay notes that most of the participants came in "very focused on their own union and kind of putting forward the things that they were working on specifically.” She saw one key role of the training to help participants see the similarities across their different groups and campaigns.

[W] hat we tried to do was to create a show that was focused on issues that really affected workers but also just working people across the city and poor people across the city. So some of the original curriculum was people going and doing interviews or stories about another group besides their own so that people would start [to] see those connections and 
than having conversations about the ways that even though there were differences in the way the mainstream media covered drivers versus, like, janitors that that no one was really getting their story told and no one was getting, like, a fair shake by the media at all. So people started to kind of build an idea for a show that was more than just these collective unions. There is definitely still a strong focus on labor but we also try to talk about the budget cuts, the casino that is proposed to come in, housing, sometimes education, sometimes we pull from the student unions radio show and share content. So, I think we are working towards something that is bigger.

Members involved with producing LJR share this view. For example, Al Robinson, a 28-year veteran shop steward and union organizer for SEIU 32BJ, pointed out that the radio show

[A]llows us to blend and coexist a network with other people even though they have different issues like there are people in the clothing industry, people in the commercial industries, people in the residential industries, and now I find myself more involved with these people all the time because now we are networking and share information and finding out that we fight the same people all the time, just at different times. So our strategies become more stronger in dealing with these people and plus when they see us coming as an umbrella they give us a little more respect or listen to us a little better.

MMP’s Labor Justice Radio (LJR) illustrates the narrative practices circle of what we call MMP's model of concentric practices. On the basis of the communicative spaces, narrative practices seek to create messages and frames, stories and understandings to suture a class identity across MMP's constitutive groups. The critical outcome of communicative spaces and narrative practices is a shared understanding of the common conditions poor and working people face, which is the basis for engaging in shared struggles.

\section{Shared Struggles}

The outer ring of our concentric practices model to generate a "common" amongst the different segments of the contemporary working class are shared struggles. These are moments when through the MMP network, different member organizations support one another in particular fights - from the right of cab drivers to unionize to the right of urban youth to a quality 
education. In these fights, MMP members utilize media and communication in an effort to "shift from multiple struggles in the city to one struggle for the city.” This is exemplified in recent work around health care.

In late 2009, MMP members became interested in the potential closure of a community hospital, Northeastern Hospital, which was run by Temple University Health System (TUHS). Serving poor and working class communities in North Philadelphia, Northeastern saw individuals that were un/underinsured, and dependent on Medicare. Consequently, Temple administrators decided to close the hospital, arguing that Northeastern was a financial drain on TUHS. The potential closure of this important community health institution concerned leaders across the city and within MMP.

In response, MMP leaders from a host of organizations came together and formed a health care committee (communicative space) that met weekly and began to strategize around the impending closure while documenting (narrative practices) both the fight around the hospital and what they saw as the dangerous conditions, particularly around maternity care, that the closure would create in North Philadelphia. Over the course of a few months, MMP members began to build relationships with different local unions that had workers at Northeastern, or other local hospitals (SEIU, PASNAP, AFSCME 1199C) as well as community groups in the area around Northeastern. MMP members went to community meetings, interviewed nurses, doctors and community members and began to knit a narrative around the importance of health care institutions as the bedrock of local community. In this process, strong relationships developed between MMP members and members of the Pennsylvania Association of Staff Nurses and Allied Professionals (PASNAP) and to a lesser degree the community group Port Richmond On Patrol Community and Civic (PROPAC). 
After a drawn out fight, which included lawsuits, community protests and an enflamed media war, Temple did shut Northeastern Hospital down. However, the idea of using health care as a core issue began to percolate within MMP. Following on the heels of the hospital closure, nurses at TUHS' core facility, Temple Main, went on strike over pay and benefits as well as concerns over patient care. The strike lasted four weeks and MMP, and particularly members of the healthcare committee mobilized on behalf of the striking workers and patients utilizing Temple’s facilities. This mobilization included organizing a rally in support of nurses that brought together high school students, taxi drivers, hotel workers and other Philadelphians to support the striking workers. The support also included an array of media coverage of the striking nurses that was featured on MMP's community website, on Philadelphia's public access TV station and on the low-power FM radio station WPEB. Further, as MMP had already established a relationship to the nurses union through the struggle around Northeastern Hospital, a nurse, who was on strike, took part in an MMP community journalism class and she used the strike as the topic of her class video project. 


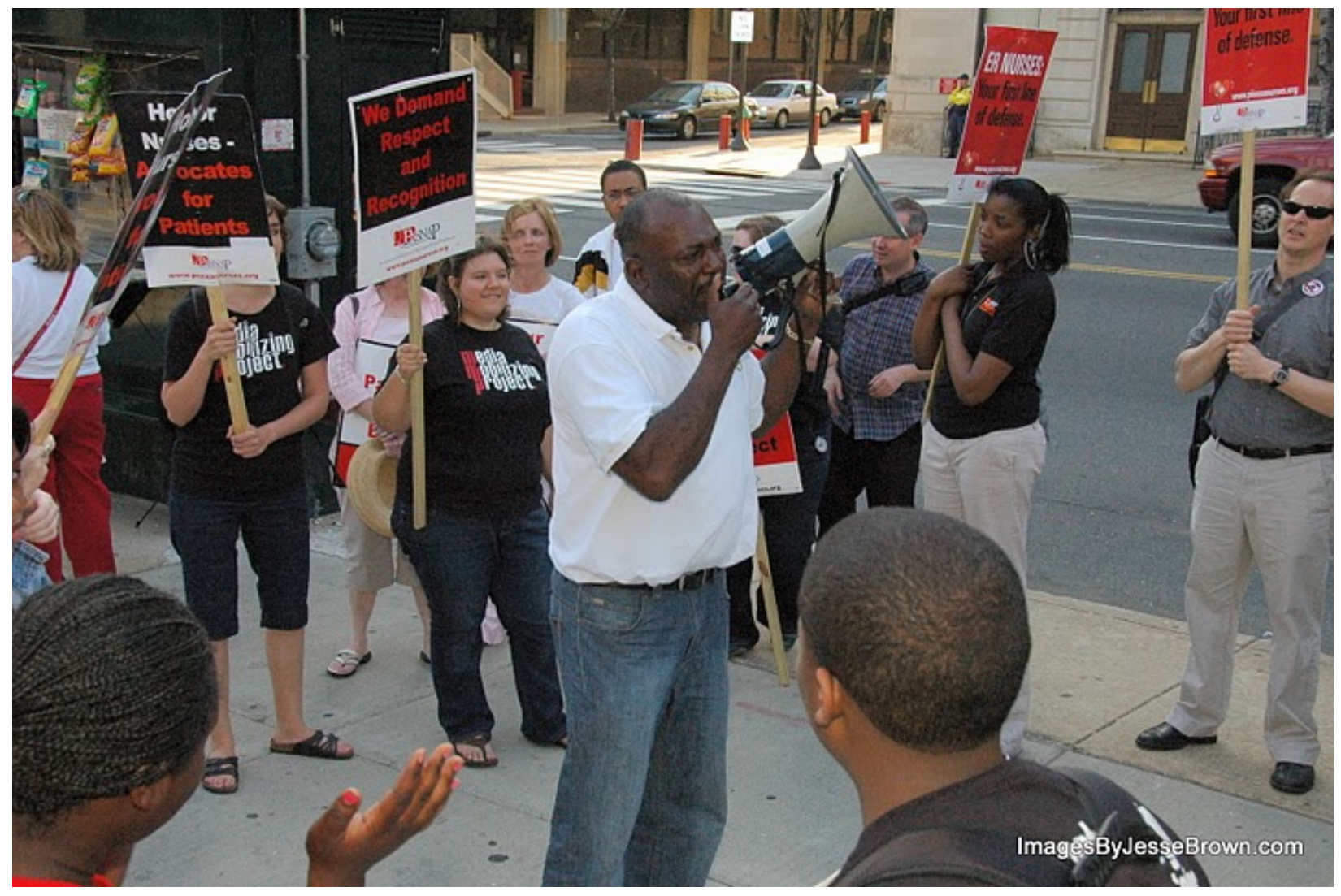

Figure 2 Ronald Blount, President of the Unified Taxi Workers Alliance, flanked by members of Media Mobilizing Project and Philadelphia Student Union during the nurses strike at Temple University in 2010. Photo by Jesse Brown

Since the end of the strike, in the spring of 2010, MMP media makers have created an hour-long documentary called "Infection in Our Healthcare System,” which they premiered in front of 250 people in the summer of 2010. The screening and other work further advanced a strategy within MMP of using health care to unite communities. Correspondingly, seven MMP members traveled to Vermont to learn about the "Healthcare is a Human Right” campaign run by the Vermont Workers’ Center, which aims to establish single-payer as the state mandated approach to health care for all. All of this activity has set the ground for a cross-organization campaign around health care. And while MMP leaders have not made a decision about whether to undertake this campaign, they are setting the stage for a fight around health care that serves the needs and interests of the poor and working class and knits this formation into a shared institutional body fighting for social change. 
Within our model of concentric practices, shared struggles, play a critical role in establishing a common adversary and a common political interest, which leads to what we see as the initial stages of class struggle, at the local level. At this point it is helpful to reintroduce Marx's thoughts on class formation when he writes, "in the struggle...this mass becomes united, and constitutes itself as a class for itself” (1978: 218). Along these lines, through the process of shared struggle, we begin to see the transformation amongst local groups and actors from a class in-itself to a class for-itself. This process however, is dependent on first establishing trust and solidarity through communicative spaces and narrative practices. Through MMP's work, which we see as a series of concentric practices, the beginnings of a shared class identity is emerging amongst MMP's constitutive groups - drivers, nurses, security guards, high school students and many others. And importantly as many pointed out, it was through their work with MMP and their use of media that this sense of unity with the broader class began to form.

\section{IV}

\section{Conclusion}

In this article, we explored the role of new media and communication in struggles over class identity and class formation by drawing on fieldwork on the Media Mobilizing Project in Philadelphia. We sought to (re)introduce the concept of class as a process of self-making in relation to a historical understanding of capitalism and capitalist relations. Moreover, we argue for the infrastructural role of media and communication in this process of suturing class identity. Finally, we offered a conceptual model of how to understand such a media-based processes of class formation by examining MMP and what we identify as MMP’s model of concentric practices towards class formation. MMP displays these concentric practices, which are comprised of three heuristically distinct components: communicative spaces, narrative practices 
and shared struggles.

MMP illustrates the structural dimension of communication for class formation and provides a particular example of how media is used by poor and working people to shape, organize and thus suture social relations across a fragmented working class. In order to expound the way media knits and thickens class identity, this article consciously emphasized promising or successful suturing processes across otherwise atomized groups. However, MMP is also indicative of the challenges and difficulties in organizing poor and working class constituencies particularly through media-based strategies. While a thorough discussion is beyond the scope of this article, it is important to note that MMP faces the challenges of most grassroots groups-it is underfunded and overworked, while working to bridge difference and disagreement.

Beyond the particularities, however, MMP provides us with a conceptual framework of how contemporary class formation is occurring through the use of media and communications in a neoliberalizing city. Concentric practices analytically describes a process of thickening and converging of the atomized and fractured neoliberal working class. It is flexible enough to be employed as heuristic framework for a host of similarly situated dynamics, aiding in teasing out and better understanding processes of class formation under neoliberal capitalism. 


\section{References}

Althusser L (1971) Lenin and Philosophy And Other Essays. New York: Monthly Review Press.

Aglietta M (1979) A Theory of Capitalist Regulation: the US Experience. London: Verso. Anderson P (1980) Arguments with English Marxism. London: Verso.

Boltanski L and Chiapello E (2005) The New Spirit of Capitalism. London: Verso,

Berger D, Funke P and Wolfson T (2011) Communication Networks, Movements and the Neoliberal City: The Media Mobilizing Project in Philadelphia. Transforming Anthropology 19(2): 187-201.

Brenner N and Theodore N (2002) Spaces of Neoliberalism: Urban Restructuring in North America and Europe. Malden: Blackwell Publishers.

Davis M (1992) City of Quartz London: Verso.

Dewey J (1954) The Public and its Problems. Athens, Ohio: Swallow Press.

Dyer-Witheford N (1999) Cyber Marx: Cycles and Circuits of Struggle in HighTechnology Capitalism. Urbana: University of Illinois Press.

Giddens A (1991) Modernity and Self Identity: Self and Society in the Late Modern Age Cambridge: Polity Press.

Goode J and Maskovsky J (2001) The New Poverty Studies: The Ethnography of Power, Politics and Impoverished People in the United States. New York: NYU Press. Funke P (2012) The Global Social Forum Rhizome: A Theoretical Framework. Globalizations 9(3): 339-351. 
Funke P (2010) The World Social Forum as Resistance Relay. New Political Science: A Journal of Politics and Culture 30(4): 439-474.

Hale, C (2008) Activist Engagements: Theory, Politics and Methods of Activist Scholarship. California: University of California Press.

Hall S (1994) "Cultural Identity and Diaspora." Colonial Discourse and Post-colonial Theory: A Reader. (Eds.) P. Williams, L, Chrisman New York: Columbia University Press.

Hardt M and Negri A (2004) Multitude: War and Democracy in the Age of Empire. New York:

Penguin Press.

Harvey D (1990) The Condition of Postmodernity: An Enquiry into the Origin of Cultural Change. New York: Willey Blackwell.

Harvey D (2005) A Brief History of Neoliberalism. Oxford: Oxford University Press.

Lash S and Urry J (1987) The End of Organized Capitalism. Cambridge: Polity Press.

Lukacs G (1968 [1923]) History and Class Consciousness. Massachusetts: MIT Press.

Mandel E (1972) Late Capitalism. London: Verso.

Marcuse P and Van Klempen (2002) Globalizing Cities: A New Spatial Order? Malden, MA: Blackwell.

Marx K (1978) The Eighteenth Brumaire of Louis Bonaparte In Tucker, RC (Ed.) The Marx Engels Reader. New York: W.W. Norton Company.

Marx K (1992) The Poverty of Philosophy. New York: International Publishers.

Massey D and Denton N (1998) American Apartheid: Segregation and the Making of the American Underclass. Cambridge: Harvard University Press. 
Media Mobilizing Project (2009). Out of Crisis, The Movement to End Poverty: Media Mobilizing Project 2009 Montage. Accessed at: http://mediamobilizing.org/outcrisis-movement-end-poverty-media-mobilizing-project-2009-montage on 10/10/2010.

Meiskins-Wood E (1995) Democracy Against Capitalism: Renewing Historical Materialism. Cambridge: Cambridge University Press.

Negri A (1989) The Politics of Subversion: A Manifesto of the Twenty-First Century. Cambridge: Polity Press.

Robinson W (2004) A Theory of Global Capitalism: Production, Class and State in a Transnational World. Baltimore: Johns Hopkins University Press.

Sanday P (1976) Anthropology and the Public Interest: Fieldwork and Theory. New York: Academic Press.

Smith N (1996) The New Urban Frontier: Gentrification and the Revanchist City. New York: Routledge.

Thompson EP (1966) The Making of the English Working Class. London: Vintage. Thompson EP (1978) The Poverty of Theory: or an Orrery of Errors. London: Merlin Press.

Wacquant L (2007) Territorial stigmatization in the age of advanced marginality Thesis Eleven. (91): 66-77.

Wolfson T (2011) Constitutive Communications and the Shimmering Project of the Multitude. Journal of Communication Inquiry. Journal of Communication Inquiry 35(4): $370-377$ 
Wolfson T (2012) From the Zapatistas to Indymedia: Dialectics and Orthodoxy in Contemporary Social Movements. Communication, Culture and Critique 5(2):

$149-170$

i This article is co-authored, as both researchers contributed equally. This research was made possible by the generous support of the Social Science Research Council. We also would like to thank Dan Berger for collaboration on an earlier and related article.

ii For a discussion of the fragmentation of the working class see Scott Lash and John Urry's The End of Organized Capitalism (1987) and Anthony Giddens Modernity and Self Identity: Self and Society in the Late Modern Age (1991)

iii Thanks to Aram Sinnreich for help with the diagram 